\title{
Transpirational Characteristics of Mangrove Species in Southern Thailand
}

\author{
Takashi Hirano, Nobutaka MonJi, Ken HaMOTANI, \\ Vipak JINTANA* and Kazutoshi YABUKI \\ College of Agriculture, Osaka Prefecture University, Sakai 593, Japan \\ ${ }^{*}$ Forest Research Office, Royal Forest Department, Bangkok 10900, Thailand
}

(Received March 27, 1996)

\begin{abstract}
In order to investigate the seasonal change of transpiration in mangrove species, the sap flow rates $\left(F_{\mathrm{s}}\right)$ in Bruguiera cylindrica were measured in southern Thailand, with a stem heat balance method. From the result, the transpiration rates $\left(T_{\mathrm{r}}\right)$ normalized by leaf area in wet and dry seasons were estimated to be 0.50 and $1.04 \mathrm{~kg} \mathrm{~m}^{-2} \mathrm{~d}^{-1}$ on the average, respectively. $T_{\mathrm{r}}$ in the dry season was rather high compared to that in the wet season. This was probably caused by the difference of meteorological conditions, such as solar radiation and air humidity. Moreover, stomatal conductance $\left(g_{\mathrm{s}}\right)$ in 4 species, Rhizophora apiculata, Ceriops decandra, Xylocarpus moluccensis and B. cylindrica, was measured in the wet season with a porometry to investigate its interspecific difference. In all the species, $g_{\mathrm{s}}$ reached a plateau at the PPFD of 200 to $400 \mu \mathrm{mol} \mathrm{m}^{-2} \mathrm{~s}^{-1}$. The plateau in $R$. apiculata was estimated to be between 150 and $250 \mathrm{mmol} \mathrm{m}^{-2} \mathrm{~s}^{-1}$; the level is similar to that in evergreen trees in Japan. However, $g_{\mathrm{s}}$ in the remaining 3 species was rather low.
\end{abstract}

\section{INTRODUCTION}

"Mangrove" is the general term given to halopytic trees and shrubs which grow in intertidal zone along tropical and subtropical coasts. In many developing countries in Southeast Asia, people have depended on mangrove forests, because the trees are a major source of firewood and building materials, and because rich mangrove ecosystems grow commercially important fishes, crabs and prawns (Clough, 1984; Aksornkoae et al., 1990). At present, however, many mangrove forests face a serious problem of deterioration. In Thailand, about half of mangrove forests have already been destroyed by conversion to aquaculture, industrial site, urbanization, tin mining, salt pan, harbor and agriculture (Jintana, 1994).

One striking feature of mangroves is their ability to grow in muddy tidal flats, where the soil is under saline and anaerobic conditions. This feature has interested many plant physiologists and ecophysiologists for a long time (Tomlinson, 1994). They have studied the salt balance, water relation, photosynthesis and functional root systems to explain the mechanisms to adapt to the unique environment (e.g., Clough, 1984 ; Yabuki et al., 1990a, b ; Aiga et al., 1995 ; Hirano et al. 1996). On the water relation, there are some field studies on transpiration rates $\left(T_{\mathrm{r}}\right)$ and stomatal conductance $\left(g_{\mathrm{s}}\right)$ in some species in North America and Australia (e.g., Moore et al., 1972, 1973; Andrews and Muller, 1985). In these studies, the seasonal change and interspecific difference in $T_{\mathrm{r}}$ and $g_{\mathrm{s}}$ were reported. In Southeast Asia, however, there is little knowledge of $T_{\mathrm{r}}$ and $g_{\mathrm{s}}$ in mangroves owing to insufficient field studies (Ong et al., 
1995).

In this study, sap mass flow rates $\left(F_{\mathrm{s}}\right)$ in Bruguiera cylindrica were measured continuously with a stem heat balance method (Sakuratani, 1981) in wet and dry seasons in Phangnga Bay, southern Thailand. $T_{\mathrm{r}}$ in $B$. cylindrica was evaluated from $F_{\mathrm{s}}$, and the relationship between $T_{\mathrm{r}}$ and meteorological elements, such as solar radiation and humidity, was investigated. Moreover, $g_{\mathrm{s}}$ in 4 species was measured with a porometry in the wet season and its interspecific difference was discussed.

\section{METHODS}

1. Study site: The measurement was conducted in a homogeneous secondary mangrove forest $\left(8^{\circ} 20^{\prime} \mathrm{N}, 98^{\circ} 27^{\prime} \mathrm{E}\right)$ in the Phangnga Bay National Park, southern Thailand, which has a tropical monsoon climate with clearly defined wet and dry seasons. The study site was located inside of the forest, about $1 \mathrm{~km}$ away from its seaward front, and was submerged with the spring high tide. From a survey of every tree with the height above $1.3 \mathrm{~m}$ in a $20 \mathrm{~m} \times 20$ $\mathrm{m}$ plot, the density of 16,675 trees ha $^{-1}$ and the average height of $3.86 \mathrm{~m}$ were obtained. Dominant species were B. cylindrica and Ceriops decandra, which occupied $70 \%$ and $14 \%$ of total trees, respectively.

2. Measurement of sap flow rate: In order to evaluate transpiration, $F_{\mathrm{s}}$ in $B$. cylindrica was measured with a stem heat balance method (Sakuratani, 1981), which is an absolute measuring technique and does not need calibration. In this method, $F_{\mathrm{s}}$ is calculated by solving heat balance of the stem heated at a constant power (Van Bavel and Van Bavel, 1990). The measurements were conducted with stem gauges (Dynagage SGA13, Dynamax Inc., USA) in a wet season, from Jul. 28 to Aug. 7 in 1994, and a late dry season, from Mar. 30 to Apr. 17 in 1995. The numbers of trees measured in the wet and dry seasons were 1 and 2, respectively; the trees with the height between 2.0 and $3.0 \mathrm{~m}$, leaf area between 1.0 and $1.4 \mathrm{~m}^{2}$, and leaf area index (LAI) between 2.2 and 2.4, were selected in a sunny place. The gauges were mounted on the stems at the height of $0.8 \mathrm{~m}$ to prevent submergence; leaf areas above the gauges were between 0.6 and $1.0 \mathrm{~m}^{2}$. Power for the heater of the gauge was provided by alkaline dry batteries with a voltage range between 4.1 and $4.6 \mathrm{~V}$. The gauges and the stems at $40 \mathrm{~mm}$ above and below the gauges were wrapped in a plastic film for waterproofing, and were wrapped fourfold in aluminum foil with a thickness of $15 \mu \mathrm{m}$ to shield against radiation. Gauge output signals were measured every $15 \mathrm{~s}$ and recorded as $10 \mathrm{~min}$ average, with a data logger (Micrologger 21X, Campbell Scientific Corp., USA). According to Van Bavel and Van Bavel (1990), gauge sheath conductance $\left(K_{\mathrm{sh}}\right)$ was determined from gauge outputs measured on a night, after removing all leaves and enclosing the remaining branches in a plastic bag. The range of $K_{\mathrm{sh}}$ observed was between 0.95 and $0.99 \mathrm{~W} \mathrm{mV}^{-1}$. Thermal conductivity $\left(K_{\mathrm{st}}\right)$ of the stems was assumed to be constant with an average value of $0.42 \mathrm{~W}$ $\mathrm{m}^{-1}{ }^{\circ} \mathrm{C}^{-1}$ (Steinberg et al., 1989).

3. Measurement of stomatal conductance: One tree of each Rhizophora apiculata, $C$. decandra and Xylocarpus moluccensis and three trees of B. cylindrica were selected ; these 4 species are all evergreen trees. The heights of these trees were between 2 and $4 \mathrm{~m}$. Stomatal conductance $\left(g_{\mathrm{s}}\right)$ to water vapour in abaxial surfaces of 4 sunlit leaves, at the height of $1 \mathrm{~m}$, of each tree was measured every $2 \mathrm{~h}$ from $10: 00$ to $18: 00$ during $5 \mathrm{~d}$ in the wet season, with a steady-state porometer (LI-1600, LI-COR Inc., USA).

4. Meteorological data: In the dry season, wet and dry bulb temperature (handmade ventilated thermocouple thermometer), wind speed (handmade cup anemometer), global radiation (pyranometer, MS -100, Eko, Japan), net radiation (net radiometer, CN-11, Eko, Japan) and amount of precipitation (tipping bucket type, Isuzu Co., Japan) were measured on 
a $15 \mathrm{~m}$ high tower built in the study site, and tide level (handmade float type tide gauge) was measured in a nearby creek. These were recorded every $30 \mathrm{~s}$ with a personal computer system. In this study, from daily averages of these meteorological data, Penman potential evapotranspiration (PET) was calculated by using the following equations (Penman, 1956, 1963),

$$
\begin{aligned}
& E_{\mathrm{T}}=10 \frac{\Delta}{\Delta+\gamma} \frac{R_{\mathrm{n}}+G}{L}+E_{\mathrm{a}} \frac{\gamma}{\Delta+\gamma}, \\
& E_{\mathrm{a}}=f(u)\left(e_{\mathrm{s}}-e\right), \\
& f(u)=0.26(0.5+0.54 u),
\end{aligned}
$$

where $E_{\mathrm{T}}$ is $\mathrm{PET}\left(\mathrm{mm} \mathrm{d}^{-1}\right), \Delta$ rate of change of saturation water vapour pressure with temperature $\left(\mathrm{hPa}{ }^{\circ} \mathrm{C}^{-1}\right), \gamma$ psychrometric constant $\left(\mathrm{hPa}{ }^{\circ} \mathrm{C}^{-1}\right), R_{\mathrm{n}}$ net radiation $\left(\mathrm{J} \mathrm{cm}^{-2} \mathrm{~d}^{-1}\right), G$ heat storage component $\left(\mathrm{J} \mathrm{cm}^{-2} \mathrm{~d}^{-1}\right), L$ heat of evaporation $\left(\mathrm{J} \mathrm{cm}^{-3}\right), E_{\mathrm{a}}$ drying power of the air $\left(\mathrm{mm} \mathrm{d}^{-1}\right), e_{\mathrm{S}}(T)$ saturation water vapour pressure at $T^{\circ} \mathrm{C}(\mathrm{hPa}), e$ water vapour pressure $(\mathrm{hPa}), u$ wind speed $\left(\mathrm{m} \mathrm{s}^{-1}\right)$ and $f(u)$ function of wind speed $\left(\mathrm{mm} \mathrm{d}^{-1} \mathrm{hPa}^{-1}\right)$. Here, the daily value of $G$ was assumed to be zero. While $f(u)$ is the function derived empirically on the basis of observations at a height of $2 \mathrm{~m}$ over short grass, wind speed and wet and dry bulb temperature used for the calculation were the measurements at $8 \mathrm{~m}$, about $2 \mathrm{~m}$ higher than the forest canopy top.

In the wet season, however, only global radiation $\left(R_{\mathrm{s}}\right)$ was measured continuously. Air temperature and humidity were monitored irregularly with the porometer.

\section{RESULTS}

\section{Sap flow and transpiration}

Hourly $F_{\mathrm{s}}$ per leaf area in $B$. cylindrica and $R_{\mathrm{s}}$ are shown in Fig. 1 . In the dry season, $F_{\mathrm{S}}$ is an average of two measurements. In both the wet and dry seasons, $F_{\mathrm{s}}$ changed together with $R_{\mathrm{s}}$ during the daytime and $F_{\mathrm{s}}$ was almost less than $10 \mathrm{~g} \mathrm{~m}^{-2} \mathrm{~h}^{-1}$ during the nighttime.

It was reported that $F_{\mathrm{s}}$ integrated for a day or longer agrees well with $T_{\mathrm{r}}$ (Steinberg et al., 1989), while $F_{\mathrm{s}}$ is not usually equal to $T_{\mathrm{r}}$ because of a change in water contents of leaves, branches and stems. Thus, daily $F_{\mathrm{s}}$ per leaf area is used below to evaluate transpiration.

In Fig. 2, $F_{\mathrm{s}}$ in two individual trees named $\mathrm{A}$ and $\mathrm{B}$ for convenience is compared; these were the measurements in the dry season. $F_{\mathrm{s}}$ in the tree B was larger than that in the A by 10 to $20 \%$ throughout the period. Since there was the same difference in hourly values between the trees A and B, this difference seems to be caused by individual variation and/or an instrumental error.

The relationship between $F_{\mathrm{s}}$ and $R_{\mathrm{s}}$ is shown in Fig. 3 to clarify the seasonal difference in $F_{\mathrm{s}} ; R_{\mathrm{s}}$ was selected as a parameter because it was measured continuously in both the seasons. Although $F_{\mathrm{s}}$ increased according to $R_{\mathrm{s}}$ which promotes transpiration mainly by increasing leaf temperature, the values of $F_{\mathrm{s}}$ and $R_{\mathrm{s}}$ were rather different between the seasons. The averages of $F_{\mathrm{s}}$ and $R_{\mathrm{s}}$ were $0.50 \mathrm{~kg} \mathrm{~m}^{-2} \mathrm{~d}^{-1}$ and $15.8 \mathrm{MJ} \mathrm{m}^{-2} \mathrm{~d}^{-1}$ in the wet season, and $1.04 \mathrm{~kg} \mathrm{~m}^{-2} \mathrm{~d}^{-1}$ and $24.3 \mathrm{MJ} \mathrm{m}^{-2} \mathrm{~d}^{-1}$ in the dry season. The averaged $F_{\mathrm{s}}$ and $R_{\mathrm{s}}$ in the wet season were 48 and $65 \%$ of those in the dry season, respectively. When $F_{\mathrm{s}}$ was averaged within the defined $R_{\mathrm{s}}$ between 20 and $25 \mathrm{MJ} \mathrm{m}^{-2} \mathrm{~d}^{-1}$, the value $\left(1.05 \mathrm{~kg} \mathrm{~m}^{-2} \mathrm{~d}^{-1}\right)$ in the dry season was 1.4 times higher than that $\left(0.75 \mathrm{~kg} \mathrm{~m}^{-2} \mathrm{~d}^{-1}\right)$ in the wet season. This seasonal difference under the same level of $R_{\mathrm{s}}$ is probably caused by that in the air humidity, which is described in the discussion.

In the dry season, the relationship between $F_{\mathrm{s}}$ and $R_{\mathrm{s}}$ in the former $4 \mathrm{~d}$ from Apr. 2 to 5 , denoted by an asterisk, differed from that in the latter $10 \mathrm{~d}$ from Apr. 6 to 15 . In order to 
(a) Wet season

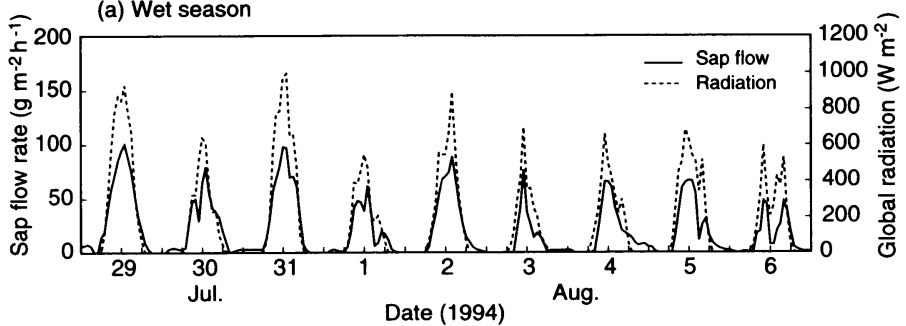

(b) Dry season
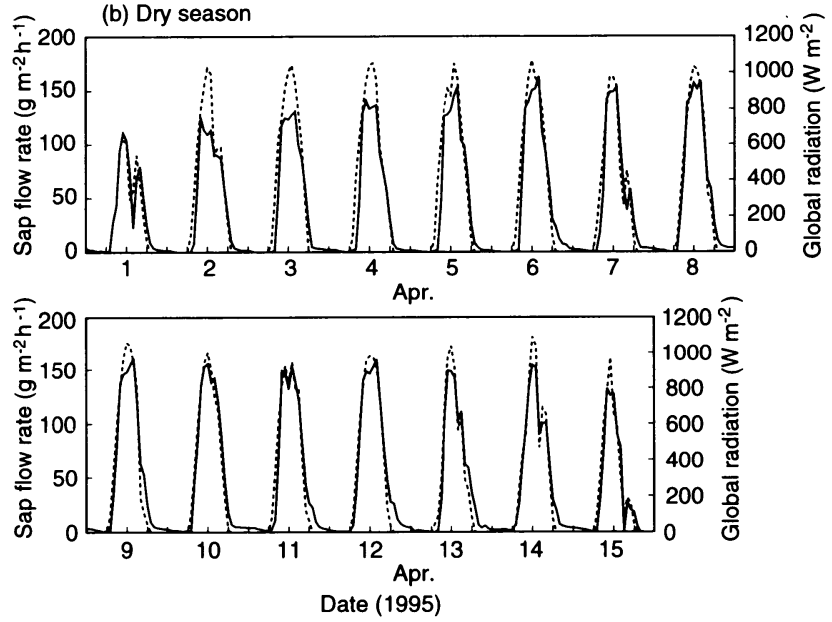

Fig. 1 Hourly sap flow rate per leaf area in B. cylindrica and global radiation in the wet and dry seasons. In the dry season, the sap flow rate is the average of two measurements.

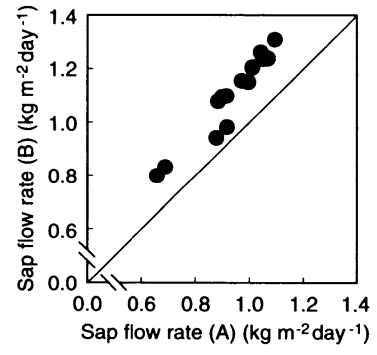

Fig. 2 Comparison between daily sap flow rates in two individual trees named $A$ and $\mathrm{B}$, of $B$. cylindrica in the dry season.

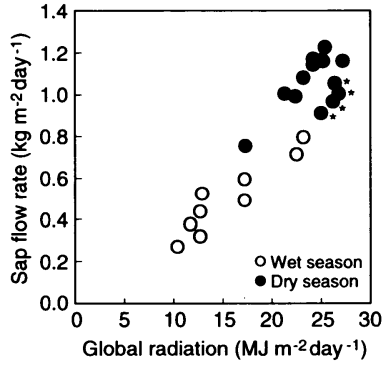

Fig. 3 Relationship between daily sap flow rate and global radiation. Each daily value in the dry season is the average of two measurements, and each point denoted by an asterisk refers to a day of Apr. 2 to 5 .

discuss this difference, the change of the daily $F_{\mathrm{s}}$ is shown in Fig. 4, together with PET and some meteorological elements (net radiation, precipitation, water vapour pressure deficit (VPD) and wind speed), and the relationship between $F_{\mathrm{s}}$ and PET is shown in Fig. $5 ; F_{\mathrm{s}}$ was calculated in the same unit $\left(\mathrm{mm} \mathrm{d}^{-1}\right)$ as PET by using the average LAI of 2.33. Since PET is the evapotranspiration from vegetation when water is rich in its rhizosphere, it depends on meteorological conditions (Eqs. (1)-(3)). The value of $F_{\mathrm{s}}$ ranged from 1.76 to $2.86 \mathrm{~mm} \mathrm{~d}^{-1}$ 

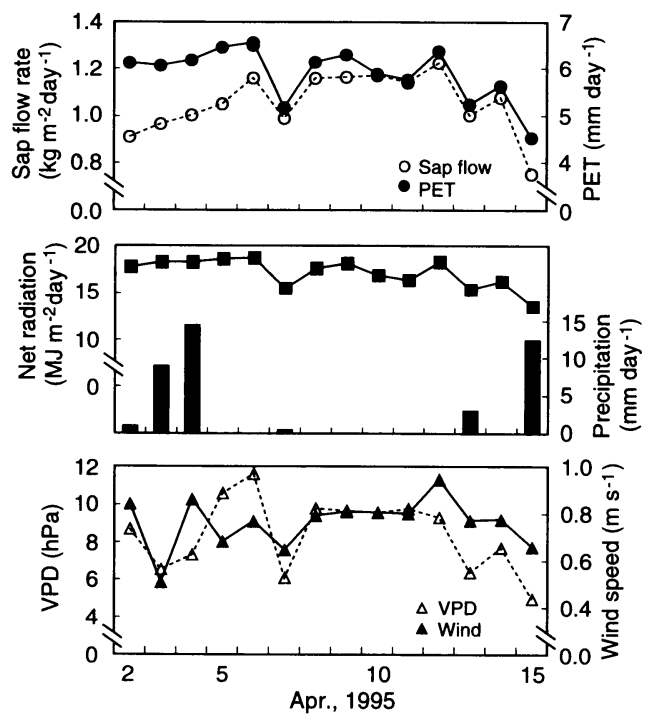

Fig. 4 Daily change of sap flow rate, PET and some meteorological elements, such as net radiation, precipitation, water vapour pressure deficit (VPD) and wind speed, in the dry season.

The VPD and wind speed are the measurements at a height of $8 \mathrm{~m}$.

with the average of $2.42 \mathrm{~mm} \mathrm{~d}^{-1}$, while PET ranged form 4.53 to $6.56 \mathrm{~mm} \mathrm{~d}^{-1}$ with the average of $5.88 \mathrm{~mm}$ $\mathrm{d}^{-1} . \quad F_{\mathrm{s}}$ changed according to PET for the days after Apr. 5 ; this shows that the transpiration was almost independent of physiological conditions, such as stomatal aperture. On the other hand, $F_{\mathrm{s}}$ increased gradually until Apr. 5, although PET was nearly constant. This discrepancy between the time courses of $F_{\mathrm{s}}$ and PET suggests the process of release from water stress. The trees under water stress for the previous dry days probably recovered through the precipitation of $38.5 \mathrm{~mm}$ from Mar. 31 to Apr. 4 .

The study site was submerged 2 times a day with

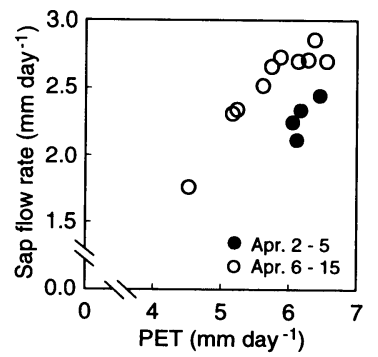

Fig. 5 Relationship between daily sap flow rate and PET in the dry season. high tide for the days from Apr. 2 to 5 and Apr. 13 to 15 , respectively. It was difficult to estimate the effects of the inundation by the high tide on the transpiration, from the data obtained in this study. To estimate this, further experiments are needed.

\section{Stomatal conductance}

The relationships between $g_{s}$ and photosynthetic photon flux density (PPFD) are shown in Fig. 6 ; these were determined in the wet season. In all the 4 species, $g_{s}$ almost reached a plateau at the PPFD between 200 and $400 \mu \mathrm{mol} \mathrm{m}^{-2} \mathrm{~s}^{-1}$, while the range of PPFD during the measurement differ from each other. Within the defined PPFD between 200 and $400 \mu \mathrm{mol}$ $\mathrm{m}^{-2} \mathrm{~s}^{-1}$, the averages of $g_{\mathrm{s}}$ in $R$. apiculata, X. moluccensis, $C$. decandra and B. cylindrica were $166,46,112$ and $74 \mathrm{mmol} \mathrm{m}^{-2} \mathrm{~s}^{-1}$, respectively. Since $g_{\mathrm{s}}$ in $R$. apiculata was 2 times higher than that in B. cylindrica, it was estimated that $T_{\mathrm{r}}$ in $R$. apiculata was also higher. By the way, no effects of the inundation by the high tide on $g_{s}$ were recognized, as described by 


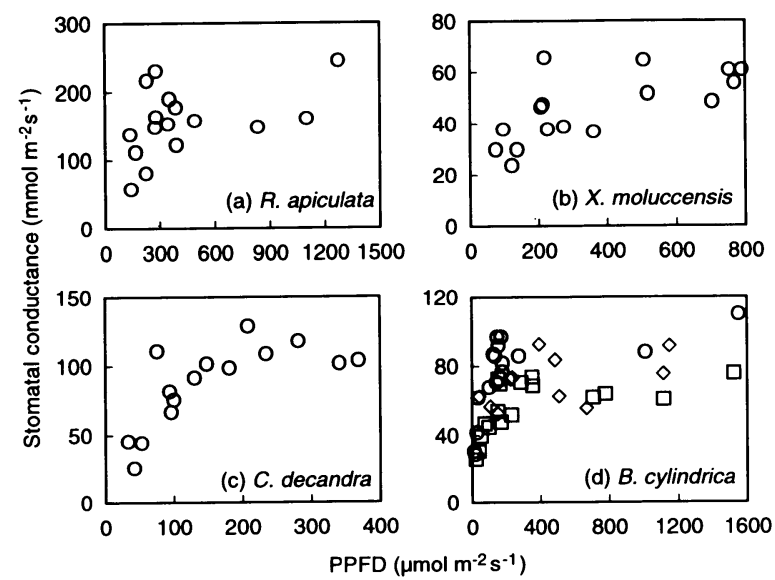

Fig. 6 Relationship between stomatal conductance and PPFD in the wet season.

Each value is the average of the measurements from 4 individual leaves. In B. cylindrica, different symbols refer to different trees.

Attiwill and Clough (1980).

\section{DISCUSSION}

The characteristics of transpiration in mangrove species are discussed by comparison between the results obtained here and reported by the other researchers.

When daily $F_{\mathrm{s}}$ is assumed to be equal to $T_{\mathrm{r}}$ (Steinberg et al., 1989), the averaged $T_{\mathrm{r}}$ in B. cylindrica was estimated to be $0.50 \mathrm{~kg} \mathrm{~m}^{-1} \mathrm{~d}^{-1}\left(1.20 \mathrm{~mm} \mathrm{~d}^{-1}\right)$ in the wet season and $1.04 \mathrm{~kg}$ $\mathrm{m}^{-2} \mathrm{~d}^{-1}\left(2.42 \mathrm{~mm} \mathrm{~d}^{-1}\right)$ in the dry season. In the dry season, $T_{\mathrm{r}}$ was $41 \%$ of the average of PET. These $T_{\mathrm{r}}$ values are rather high compared to that in $R$. mangle in South Florida, which was evaluated by Miller (1972) by using a heat balance model; he reported $T_{\mathrm{r}}$ between 0.42 and $0.49 \mathrm{~mm} \mathrm{~d}^{-1}$ in Jan. and between 0.84 and $1.21 \mathrm{~mm} \mathrm{~d}^{-1}$ in Jun. This difference in $T_{\mathrm{r}}$ between $B$. cylindrica and $R$. mangle is probably caused by differences between species and/or methods, because the meteorological conditions, such as air temperature and VPD, of these 2 studies resemble each other.

The interspecific difference and seasonal change in $g_{\mathrm{s}}$ in mangrove species were reported by Moore et al. $(1972,1973)$, who conducted field experiments in South Florida. On the mangroves growing in Australia, R. apiculata, Avicennia marina and B. gymnorrhiza, $g_{\mathrm{s}}$ was about 150,150 and $100 \mathrm{mmol} \mathrm{m}^{-2} \mathrm{~s}^{-1}$, respectively under the PPFD of $1,000 \mu \mathrm{mol} \mathrm{m}^{-2} \mathrm{~s}^{-1}$ and about 150,100 and $50 \mathrm{mmol} \mathrm{m}^{-2} \mathrm{~s}^{-1}$ under the PPFD of $2,000 \mu \mathrm{mol} \mathrm{m}^{-2} \mathrm{~s}^{-1}$, at the optimum leaf temperature (Ball et al., 1988). This value of $g_{\mathrm{s}}$ in $R$. apiculata is similar to that in our study. Moreover, it was reported that $g_{\mathrm{s}}$ in mangrove species decreased as air humidity decreased (Ball and Farquhar, 1984; Andrews and Muller, 1985), in the same manner as ordinary terrestrial plants (Schulze et al., 1987). In this study, $g_{\mathrm{s}}$ in the dry season was not measured. However, it estimated that $g_{\mathrm{s}}$ in the dry season was lower than that in the wet season, because the VPD averaged for daytime $(10: 00$ to $18: 00)$ in the dry season $(17 \mathrm{hPa})$ was higher than that in the wet season $(10 \mathrm{hPa})$.

On tropical terrestrial trees, $g_{\mathrm{s}}$ between 100 and $150 \mathrm{mmol} \mathrm{m}^{-2} \mathrm{~s}^{-1}$ in Argyrodendron peralatum in Australian rain forests was reported (Doley et al., 1988). Moreover, in seasonally dry forests with evergreen and deciduous trees in Costa Rica, the averages of $g_{\mathrm{s}}$ in some species were between 200 and $300 \mathrm{mmol} \mathrm{m}^{-2} \mathrm{~s}^{-1}$ at a moist site (10 species) and between 100 
and $150 \mathrm{mmol} \mathrm{m}^{-2} \mathrm{~s}^{-1}$ at a dry site (7 species) in an early dry season (Martin et al., 1994). In planted forests in Nigeria, the maximum values of $g_{\mathrm{s}}$ in Gmelia arborea for pulpwood and Tectona grandis (teak) for poles and saw timber were about 600 and $1,000 \mathrm{mmol} \mathrm{m}^{-2} \mathrm{~s}^{-1}$, respectively in a dry season (Whitehead et al., 1981), and $1,200 \mathrm{mmol} \mathrm{m}^{-2} \mathrm{~s}^{-1}$ in a wet season (Grace et al., 1982). Furthermore, $T_{\mathrm{r}}$ in Guiera senegalensis in savanna in Niger was estimated to be between 1.5 and $2.0 \mathrm{~mm} \mathrm{~d}^{-1}$ in a wet season, by using $F_{\mathrm{s}}$ measured with the same way as this study (Allen and Grime, 1995).

On temperate trees, Fujinuma et al. (1985) measured $g_{s}$ in 113 deciduous species and 35 evergreen species in a summer season, in Japan, with a LI-COR's steady-state porometer. They reported that the maximum $g_{\mathrm{s}}$ ranged from 100 to $1,000 \mathrm{mmol} \mathrm{m}^{-2} \mathrm{~s}^{-1}$, and the averages of deciduous and evergreen trees were 350 and $200 \mathrm{mmol} \mathrm{m}^{-2} \mathrm{~s}^{-1}$, respectively. Moreover, by using $F_{\mathrm{s}}$ measured with a heat pulse method, $T_{\mathrm{r}}$ in Maritime pine (Pinus pinaster) in France was estimated to be $3.6 \mathrm{~mm} \mathrm{~d}^{-1}$ at maximum, which was 55\% of PET (Granier et al., 1990). In the study, a strong positive correlation between $T_{\mathrm{r}}$ and PET was reported.

By comparison between these terrestrial trees and the 4 mangrove species in this study, it can be said that the $g_{\mathrm{s}}$ level of $R$. apiculata in a wet season is almost similar to that in evergreen trees in Japan. However, $g_{\mathrm{s}}$ in the remaining 3 species, especially in $X$. moluccensis was rather low.

Needless to say, further field experiment with many trees is needed, because this conclusion on transpiration was derived from the result obtained with limited trees. In order to discuss the effects of tide level on transpiration, a long-term experiment is also needed. Furthermore, it is necessary to measure $g_{\mathrm{s}}$ in a dry season to investigate its seasonal change.

We acknowledge Dr. Sanga Sabasri and Ms. Prapasri Thanasukarn, The National Research Council of Thailand, Dr. Jitt Kongsanchai, Royal Forest Department, and Professors Ichiro Aiga and Makoto Kiyota, Osaka Prefecture University, for their constant support throughout the experiment, and Messrs. Hideki Ueyama and Satoshi Fukagawa, Osaka Prefecture University, and Messrs. Somsak Piriyayotha, Chaisit Trakulsiripanich and their staff in the Royal Forest Department, for helping us in the field work. This research was supported by a grant from Nippon Life Insurance Foundation.

\section{REFERENCES}

Aiga, I., Nakano, Y., Ohki, S., Kitaya, Y., Yabuki, K. 1995. Photosynthetic $\mathrm{CO}_{2}$ fixation in pneumatophores of gray mangrove, Avicennia marina. Environ. Control in Biol. 33 : 97-101.

Aksornkoae, S., Priebprom, S., Saraya, A., Kongsangchai, J. 1990. Mangrove resources and the socioeconomics of dwellers in mangrove forests in Thailand. In "Man in the Mangroves" (ed. by Kunstadter, P., Bird, E., Sabasri, S.), The United Nations University, Tokyo, p 11-43.

Allen, S. J., Grime, V. L. 1995. Measurements of transpiration from savannah shrubs using sap flow gauges. Agric. For. Meteorol. $75: 23-41$.

Andrews, T. J., Muller, G. J. 1985. Photosynthetic gas exchange of the mangrove, Rhizophora stylosa Griff., in its natural environment. Oecologia 65 : 449-455.

Attiwill, P. M., Clough, B. F. $\quad$ 1980. Carbon dioxide and water vapour exchange in the white mangrove. Photosynthetica $14: 40-47$.

Ball, M. C., Cowan, I. R., Farquhar, G. D. 1988. Maintenance of leaf temperature and the optimisation of carbon gain in relation to water loss in a tropical mangrove forest. Aust. J. Plant Physiol. 15 : 263 276.

Ball, M. C., Farquhar, G. D. 1984. Photosynthetic and stomatal responses of two mangrove species, Aegiceras corniculatum and Avicennia marina, to long term salinity and humidity conditions. Plant Physiol. 74 : 1-6.

Clough, B. F. 1984. Mangroves. In "Control of Crop Productivity," Academic Press, Australia, p 253- 
268.

Doley, D., Unwin, G. L., Yates, D. J. 1988. Spatial and temporal distribution of photosynthesis and transpiration by single leaves in a rainforest tree, Argyrodendron peralatum. Aust. J. Plant Physiol. 15 : 317-326.

Fujinuma, Y., Machida, T., Okano, K., Natori, T., Totsuka, T. 1985. Screening of air-filtering plants -Interspecific difference in characteristics of leaf diffusive resistance among broad-leaved tree species. Res. Rep. Nat1. Inst. Environ. Stud., Jpn. 82 : 13-28 (in Japanese with English summary).

Grace, J., Okali, D. U. U., Fasehun, F. E. 1982. Stomatal conductance of two tropical trees during the wet season in Nigeria. J. Appl. Ecol. 19 : 659-670.

Granier, A., Bobay, V., Gash, J. H. C., Gelpe, J., Saugier, B., Shuttleworth, W. J. $1990 . \quad$ Vapour flux density and transpiration rate comparisons in a stand of Maritime pine (Pinus pinaster Ait.) in Les Landes forest. Agric. For. Meteorol. 51 : 309-319.

Hirano, T., Aiga, I., Monji, N., Hamotani, K., Jintana, V., Ishikawa, T., Yabuki, K. 1996. Radiation environment of mangrove pneumatopores in the brackish water. Environ. Control in Biol. 34: 87-90.

Jintana, V. 1994. Rehabilitation of mangrove ecosystem in Thailand. UNESCO-MAB Southeast and East Asia Regional Seminar on Ecosystem Rehabitation on Ecotone III. p 1-6.

Martin, C. E., Loeschen, V. S., Borchert, R. 1994. Photosynthesis and leaf longevity in trees of tropical deciduous forest in Costa Rica. Photosynthetica 30 : 341-351.

Miller, P. C. 1972. Bioclimate, leaf temperature, and primary production in red mangrove canopies in south Florida. Ecology 53 : 22-45.

Moore, R. T., Miller, P. C., Albright, D., Tieszen, L. L. 1972. Comparative gas exchange characteristics of three mangrove species during the winter. Photosynthetica $6: 387-393$.

Moore, R. T., Miller, P C., Ehleringer, J., Lawrence, W. 1973. Seasonal trends in gas exchange characteristics of three mangrove species. Photosynthetica $7: 387-394$.

Ong, J., Gong, W. K., Clough, B. F. 1995. Structure and productivity of a 20-year-old stand of Rhizophora apiculata Bl. mangrove forest. J. Biogeography 22 : 417-424.

Penman, H. L. 1956. Estimating evaporation. Trans. Am. Geophys. Union 37 : 43-50.

Penman, H. L. 1963. Vegetation and Hydrology, Tech. Commun. 53, Commonwealth Bureau of Soils, Harpenden, England, pp 124.

Sakuratani, T. 1981. A heat balance method for measuring water flux in the stem of intact plants. J. Agric. Meteorol. 37 : 9-17.

Schulze, E. D., Turner, N. C., Gollan, T., Shackel, K. A. 1987. Stomatal responses to air humidity and soil drought. In "Stomatal Function" (ed. by Zeiger, E., Farquhar, G. D., Cowan, I. R.), Stanford University Press, Stanford, p 311-321.

Steinberg, S., Van Bavel, C. H. M., McFarland, M. J. 1989. A gauge to measure mass flow rate of sap in stems and trunks of woody plants. J. Am. Soc. Hortic. Sci. $114: 466-472$.

Tomlinson, P. B. 1994. The Botany of Mangroves (Cambridge Tropical Biology Series). Cambridge University Press, Cambridge, pp 419.

Van Bavel, M. G., Van Bavel, C. H. M. 1990. Dynagage Installation and Operation Manual. Dynamax Inc., Houston, pp 80.

Whitehead, D., Okali, D. U. U., Fasehun, F. E. 1981. Stomatal response to environmental variables in two tropical forest species during the dry season in Nigeria. J. Appl. Ecol. 18 : 571-587.

Yabuki, K., Kitaya, Y., Sugi, J. 1990a. Studies on the function of mangrove pneumatophores (1). Environ. Control in Biol. 28 : 95-98 (in Japanese with English summary).

Yabuki, K., Kitaya, Y., Sugi, J. 1990b. Studies on the function of mangrove pneumatophores (2). Environ. Control in Biol. 28 : 99-102 (in Japanese with English summary). 


\section{〈和文抄録〉}

\section{タイ南部におけるマングローブの蒸散特性}

平野高司・文字信貴・鱧谷＼cjkstart㥶・ウィパック チンタナ*・矢吹萬壽

大阪府立大学農学部, *夕イ王立森林庁

マングローブの蒸散の季節変化を調べるために, タイ南部において Bruguiera cylindrica の茎内 流量を茎熱収支法を用いて雨季と乾季に野外測定した。 その結果, B. cylindrica の葉面積当たりの 蒸散速度は, 雨季と乾季でそれぞれ $0.50,1.04 \mathrm{~kg} \mathrm{~m}^{-2} \mathrm{~d}^{-1}$ と評価された。この季節間差は, 主に日 射量や大気湿度の違いによるものと考えられた。また, 蒸散特性の種間差を調べるために, 雨季に 4 種類のマングローブ (Rhizophora apiculata, Ceriops decandra, Xylocarpus moluccensis, B. cylindrica) の気孔コンダクタンス $\left(g_{\mathrm{s}}\right)$ をポロメータ法により測定した。 $g_{\mathrm{s}}$ は，4樹種ともに 200〜400 $\mu \mathrm{mol} \mathrm{m} \mathrm{m}^{-2} \mathrm{~s}^{-1}$ 以上の PPFD でほぼ一定（光飽和）となった. そのときの R. apiculata の $g_{\mathrm{s}}$ は $150 \sim$ $250 \mathrm{mmol} \mathrm{m}^{-2} \mathrm{~s}^{-1}$ であり, 日本の常緑樹での平均値とほほ同程度であった。一方, 残りの 3 樹種の $g_{\mathrm{s}}$ は，かなり低いレベルであった. 